地筫学雑誌 第 78 巻 第 5 号 273 - 274 ペーシ，1972 年 5 月

\title{
遠藤 毅・中山俊雄・川島真一：東京における試錐コアから産出したオノミチキサンゴについて
}

Takeshi Endo, Toshio Nakayama and Shinichi Kawashuma : Discovery of Fossil Dendrophyllia cribrosa (de Haan) from Drilling Core in Tokyo

(1971 年 10 月 18 日 受理)

\section{1. まえがき}

東京都は地盤沈下調查事業の一環として，西部の山岳 地带を除く都内全域にわたり，試錐（深さ300～1000m） に上る地質・土質調查と観測井による地下水位調査を計 画し，現在実施中であるが，それらのらち昭和 45 年 (1970) 足立区宮城二丁目（第1 図）にて施工した試錐 コアからオノミチキサンゴの化石の産出をみたので紹介 する。

\section{2. 試錐結果の概要}

試錐樑度は $450 \mathrm{~m}$ で，ダブルコアチューブを使用し た、磂および粗砂層を除き大半をコアの状態で観察する ことができた，地質柱状図（第 2 図）に示したように深 さ $20 \mathrm{~m}$ までが有楽町層, 深さ $20 \sim 29 \mathrm{~m}$ が七号地層, 深さ 29〜 $54 \mathrm{~m}$ が東京層に相当すると思われる. つぎに 江戸川層群と上総層群の境界であるが，この両層群の境 界設定も今回の調查目的の 1 つであるため層相調查のほ かに花粉・珪藻・有孔虫分析, 重鉱物分析を実施した.

層相から久ると，深さ $150 \mathrm{~m}$ までは粘性上・砂磂層が 発達しているが，その深さをこえると砂層の発達が顕著 になる。深さ $300 \mathrm{~m}$ 付近からは砂の粒径が細かくなり,

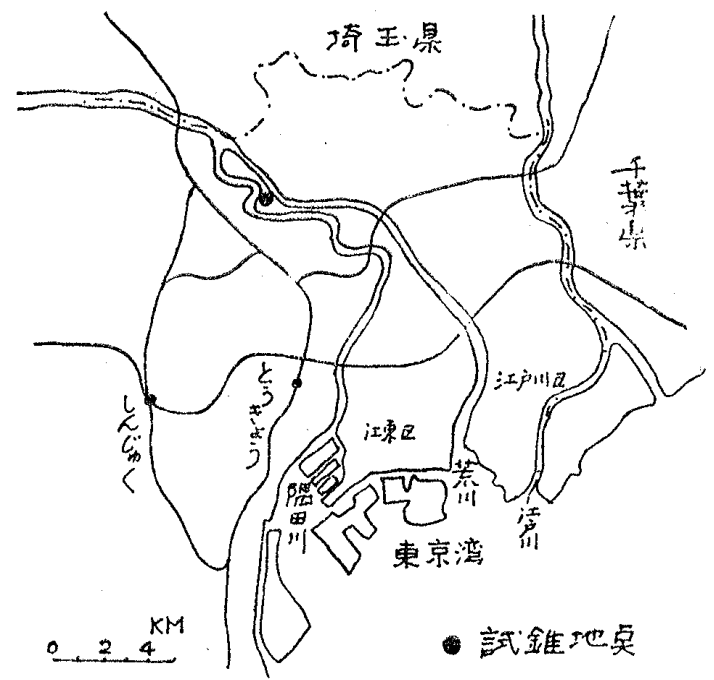

第 1 図試錐地点
極微細砂から砂質泥岩へと変化している. また，今回の 調査で注目すべきことは，媣さ $50 \mathrm{~m}$ から孔底にいたる までほぼ全層にわたり浮石粒が認められたことである。

このよらな層相から判断すると, 両層群の境界は深さ $300 \mathrm{~m}$ 付近かと思われる. しかし，微化石分析結果によ ると，有孔虫は深さ $226 \mathrm{~m}$ 付近を境に種の組合せが著し く異なり，また花粉によると深さ $200 \mathrm{~m}$ 付近をこえると Metasequia, Nissa, Liquidambar の産出文るょうにな

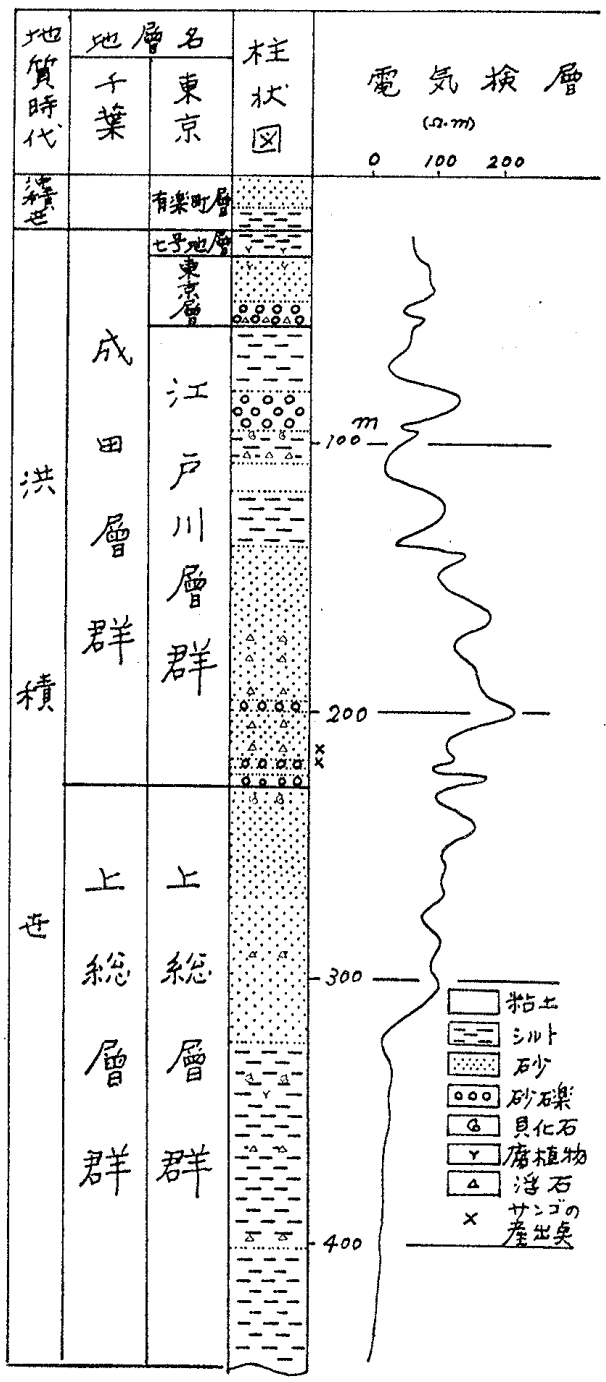

第2図地質柱状因 


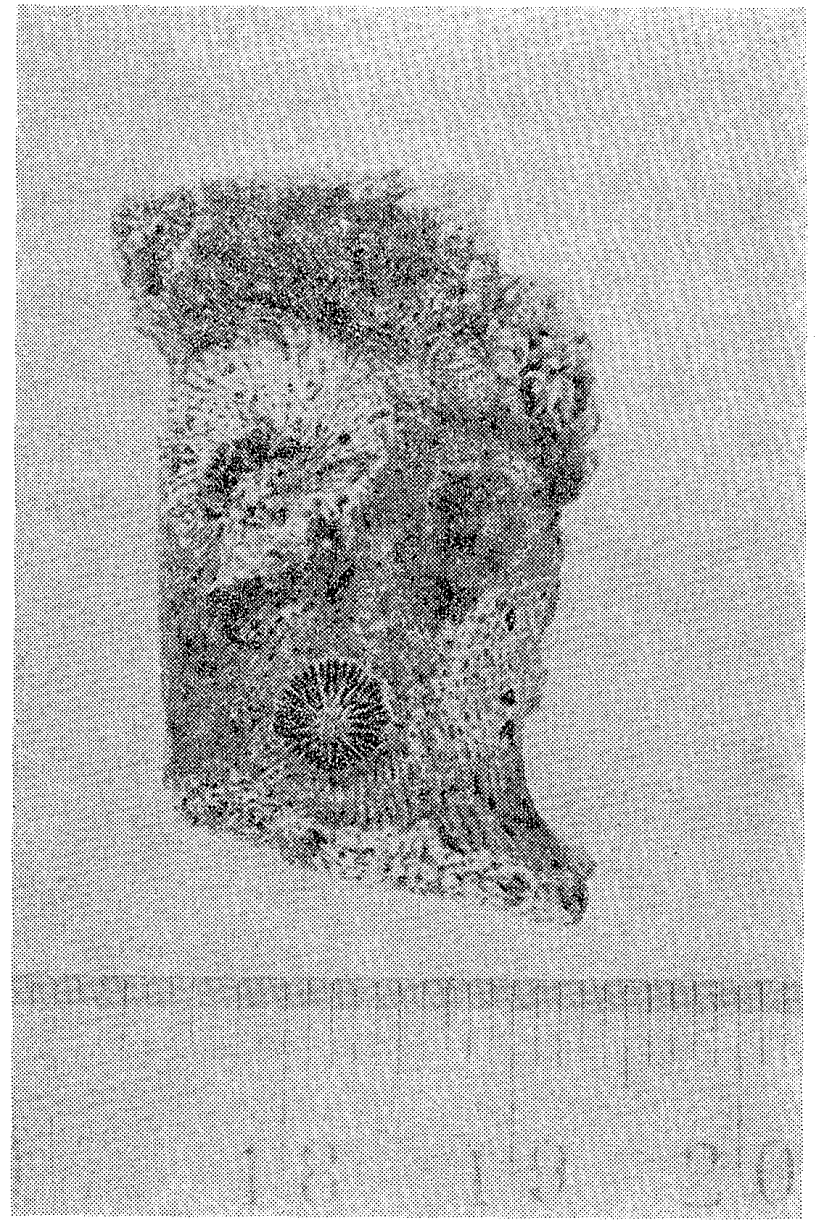

第3図コアから産出したオノミチホサンゴ

る.このように微化石分析結果による両層群の境界は深 さ $220 \mathrm{~m}$ 付近である.

\section{3. サンゴの産出とその意義}

サンゴの産出箇所は 2 つり，1つは深さ $214 \mathrm{~m}$ の細 砂層中, 他の 1 つ注深さ $219 \mathrm{~m}$ の砂磪尿中で両者共同一 種である。前者は亜円状であるが，後者は写㥲（符 3 図）でタるようにビットによる切断面が判然とし保存 も良くほ汪琣置に栱息していたものと思われる。江
口元起の同定によると，このサンゴはオノミチキサンゴ (Dendrophyllia cribrosa(de Haan)) であり, 現生種とし て知られているが（江口，1935，YABE H. and EGUGH M., 1944, 生物学御研究所, 1968), 化石としての産出 は最初であることが判明した. 現生のオノミテキサンゴ の榡息は，日本周辺の造礁サンゴが消失した北側の装。

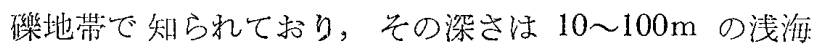
である(江口，1935）。

このオノミチキサンゴの産出は, 深度が微化石分析に よる江戸川層群と上総層群の境界付近であること，また 先述したように現生種の棲息環境が判明していることか ら当時の江戸川檿群基底の堆積環境を知る手がかりとな ること等から意義あるものと思う。

\section{4.あとがき}

微化石分析，試錐等比上万東京の符四紀層の調查結舆 については近い将来報告することとして，今回は才ノ之 テキサンゴの化石産出の紹介にとどめた。

試錐安担当したダイヤコンサルタント K.K. の田村 美怕，岩沢英明の雨氏，写真撮影をしていただいた杀 雄二東京家政大学满印，発契の機会をいただいた會持交 雄東京都土水技術研究所長に感謝する。安た, 江口元起 東京家政大学教授に注化石の鑑定，その他折りにふて机て 御指尊をいただき心から感謝する次第である。

\section{交献}

江口元起 (1935), 東京学及びその周辺のサンゴ，植物， 動物, vol. 4, no. 2, p. 66, Fig. 1 .

生物学御研究所 (1968), 相模湾産七ド口㺺䎁扮よび石 㻦瑚類，p. C8, Pl. C2，Fig. 2, P1. C21, Fig. 3, 4. YABE H. and EGuchr, M. (1944), Note on a Fossil Dendrophyllia from the Miocene of the Tugaru District in Aomori-ken. Jour. Geol. Soc. Japan, vol. 51, p. 135-137. 